DOI https://doi.org/10.18551/rjoas.2020-12.08

\title{
THE EFFECT OF SUSTAINABILITY REPORT DISCLOSURE ON MARKET AND ENVIRONMENTAL PERFORMANCE
}

\author{
Putri Pratiwi Herdianti \\ Department of Accounting, Faculty of Economics and Business, \\ University of Airlangga, Surabaya, Indonesia \\ E-mail: pratiwi.herdianti.putri-2015@feb.unair.ac.id
}

\begin{abstract}
This study purpose to provide empirical evidence about the effect of sustainability report disclosure on market and environmental performance. The object of research is companies that publish sustainability reports on Indonesia Stock Exchange in Period 2014-2018. The sampling techniques used are purposive sampling method. The dependent variable is market performance as measured by Tobin's $Q$ and moderating variable is environmental performance as measured by PROPER (Corporate Performance Rating Assessment) initiated by the Ministry of Environment and Forestry of The Republic Indonesia. While the independent variable is Sustainability Report Disclosure as measured by SRDI. The data analysis of this study is using Moderated Regression Analysis (MRA). The results of this study indicate the findings that the sustainability report disclosure has a significant effect on market performance and the second finding shows that environmental performance as moderation weakens the effect of sustainability report disclosure on market performance. The reason why is because there are still not many company that publish sustainability reports in Indonesia, due to the inconsistency of the company in issuing sustainability reports every year, the government needs to issue regulations so that more companies publish sustainability reports consistently.
\end{abstract}

\section{KEY WORDS}

Sustainability report, environmental, PROPER, market, performance.

Sustainability Report is report published by a company that not only contains information about finance performance but also provides information on the social and environmental fields. Companies began to abandon the single bottom line concept and began to shift to the triple bottom line Profit, People, and Planet. It means, companies not only paying attention to profit but also pays attention to and is directly involved in the welfare of the community (people), especially around the company premises and participate in preserving the environment (Planet) (Elkington, 1999). Sustainability Reports are published to encourage companies to carry out activities and interact with the community, as well as foster a sense of concern for their environment.

Sustainability Report is a disclosure regarding the breadth and incidents in a particular reporting period in the context of the organization's commitment, strategy and approach to management which is prepared based on GRI reporting standards. GRI reporting standards are standards that ultimately serve as a reference and are intended as a framework for general acceptance in relation to reporting company performance in the economic, social, and environmental fields of a company.

Company's reputation, value and, consumer confidence can be increased by issuing sustainability report. High reputation and consumer trust will increase consumer loyalty and directly proportional to the increase in company income. Therefore, sustainability reports are often used by companies as a tool to attract consumers because they will prefer products form company who has more concern about environment besides sustainability report are also used as a tool to attract investors' attention in investing.

Research regarding sustainability report has inconsistent results. In research by Michael Adams, Barry Thornton, and Mohammad Sepehri (2011) which revealed that sustainability reporting is used to build a company in the long term so that it must be 
positively correlated with company performance so that it can maximize long-term shareholder wealth. This research supported by research form Ririan Dian Pratiwi and Anna Sumaryati (2014) which states that sustainability report disclosure affects financial performance. Likewise with Dewi's research (2015) which shows that there is a positive influence on sustainability report as measured by sustainability disclosure index (SRDI) in return in assetsm but not in accordance with the result of research by Priyanka Anggarwal (2013) which tested the effect of sustainability reporting disclosure in company performance in companies in India which resulted sustainability report having no effect on the company's financial performance. Lesmana Tarigan (2014) in his research divides the dimensions of sustainability report inti three main parts, namely economic, environmental, and social it also shows that the economic and environmental dimension of the sustainability report does negative significant effect on financial performance.

Several previous studies, such as research by Sarumpaet (2005) didn't find a relationship between environmental performance and financial performance, this is supported by research by Rakhiemah and Agustia (200) which also didn't find an effect between environmental performance on financial performance. However, it is inversely proportional to Darnall (2008) in his research which found that environmental performance has a positive effect in financial performance.

Researches want to focus more in conducting research in testing the impact of sustainability reporting on the company's market and environmental performance. Researches used a sample of publicy listed companies on IDX, which published sustainability report in period 2014-2018 and measure market performance with Tobins'Q because its considered the most capable of providing the best information, because in Tobins' $Q$ includes all elements of debt and share capital of the company. Meanwhile, environmental performance is measured using PROPER.

\section{THEORY AND DEVELOPMENT OF HYPOTHESIS}

Stakeholder are individuals, groups of people, communities, or society, either as a whole or partially, who have relationships and interests in the company such as shareholders, consumers, creditors, suppliers, governments, partners, or the community and other parties, so stakeholder theory believes that an entity must provide benefits not only for its own interests but also for its stakeholders (Ghozali and Chariri, 2007).

The stronger relationship between corporation and stakeholder can be increase corporate business, but on the other hand, if relationship between corporation and stakeholder get worse, the business will be increasingly difficult. Good relationship between corporations and stakeholders are based on trust, respect, a good cooperation. According to Totok's research (2014), this theory is a strategic management concept, which has the goal of helping corporations in strengthening relationships with external parties and developing competitive advantage.

Research by Kasmawati (2014) revealed that legitimacy can form a string mechanism for understanding voluntary environmental and social disclosures made by companies. In the theory of legitimacy, it is advisable for companies to convince the public that the company's activities and company performance can be accepted, steps to be taken are through a communication strategy by providing information that can be trusted and believed to be true.

Companies or organizations need legitimacy theory because they have boundaries, norms, values, and social regulations that are able to impose boundaries on the company so that the company can pay more attention to social interest and their impact in the form of social reactions that will be caused. Organizations with legitimate status will be more considered as trustworthy and worthy organizations.

The report published by the company is a liaison between company and external parties in the form of information. If the company's performance is good, it will give a positive signal to the good relationship between them, so that there is no doubt for investors to invest in the company. Signal theory explains what actions the company must take to provide a 
single in the form of information to interested parties, this action can then be used for decision making by providing an illustration of the company's condition.

Hypothesis Development. The value of the company will grow in sustainability manner if the company pays attention to all dimensions of the sustainability report because the more company value increases, the more attractive it is to investors (Latifah and Luhur, 2017). As in Gunawan and Mayangsari's research (2015) which reveals that sustainability report will increase the value of the company in terms of stock prices and company profits as a result of investors investing in the company. This is supported by the results of Safitri and Fidiana's research (2014) which showing a positives effect on financial performance. Based on the study above, the first hypothesis can be formulated as follows:

$\mathrm{H} 1$ : Sustainability report disclosure has a positive effect on market performance.

To be able to find out how the market value of the company, in this study was measured using the Tobin's $Q$. Research in the effect of sustainability report disclosure on form value shows inconsistent results, some support and some have a significant negative effect, therefore researches include environmental performance variables as a moderating variable.

This is supported by several previous researches who also used environmental performance variables, namely the Almilia and Wijayanti's study (2007) who found that there was a significant influence between environmental performance and economic performance so that the company's environmental performance had an impact on the company's financial performance which was reflected in the level of return. Company annual returns compared to industry returns. Then the research if Dian and Aldilla (2009) whose research results prove the acceptance of $\mathrm{H} 1$, namely good environmental performance (green) as measured by PROPER has a significant positive effect on CSR thus the second hypothesis is formulated as follows:

$\mathrm{H}$ 2: Environmental performance as measured by PROPER moderates the effect of sustainability report disclosure on market performance.

\section{METHODS OF RESEARCH}

This research is quantitative research, with a population are companies listed on the Indonesia Stock Exchange or IDX which publishes sustainability reports in 2014-2018. Researches used the data obtained through www.idx.co.id and also on the web of each company. Researcher used purposive sampling method to selection of samples, with the following criteria: 1) Company must publish annual reports during 2014-2018; 2) Company must publish sustainability reports or disclose other social responsibility information during 2014-2016; 3) Company that must publish financial statements for five consecutive years 2014-2018; 4) Entered into the PROPER category by the Ministry of Environment and Forestry. The dependent variable is market performance which measured by Tobin's $Q$. information provided on the measurement of the ration on the Tobin's $Q$ value is considered to be the best and most comprehensive in illustrating firm value. It contains all the elements of debt and share capital belonging to company. This is supported by Safitri and Fidiana in their research which states the same thing. Apart from common stock and company equity, Tobins's $Q$ also values all company assets. This can reflect that the company does not only focus on single type of investment. The following is the Tobin's $Q$ measurement formula developed by Chung and Pruitt (1994):

$$
\text { Tobin's } \mathrm{Q}=\frac{(M V S+D)}{T A}
$$

Where: MVS is market value of all outstanding shares; D is Debt and TA is Total Assets. Debt is the amount of the market obligation value, where this value can be calculated using the following equation:

$$
D=(A V C L-A V C A)+A V L T D
$$

Where: AVCL is Accounting Value of the Firm's Current Liabilities (Short Term Debt + Taxes Payable) then AVCA is Accounting Value of the Firm's Current Assets (Cash + Account 
Receivable + Inventories) and AVLTD is Accounting Value of the Firm's Long Term Debt (Long Term Debt).

In this study, moderating variables is environmental performance which measured by PROPER by Ministry of Environment and Forestry. PROPER is one of the instruments or ways to conduct an assessment by the Ministry of Environment and Forestry for company compliance in managing its companies in the environmental sector. Assessment on PROPER uses a color indicator. Gold color is the highest indicator in the PROPER ranking and is the best ranking. In the next sequence, there are green, blue, and red colors. The worst rating in the PROPER assessment is indicated by the color black. A numerical score ranging from 1 to 5 will be given according to the order of the color ranking in gold for the highest score.

Sustainability report disclosure is used as independent variables in this study. This variable measured through Sustainability Report Disclosure Index or SRDI. Sustainability report is a report published by a company to reveal what activities the company undertakes during the current year, especially on social activities covering aspects if the economy, environment, human rights, labor practices and decent work, social life, and product responsibility. Independent variables were measured using the sustainability report disclosure index in shich there was a GRI-G4 assessment with a total of 149 items. The score given was 1 for the items disclosed and given a score of 0 if not disclosed. The next score will be added up to get the total score for each company as the final result then calculated using the SRDI formula (Gunawan and Mayangsari, 2015). RSDI calculation formula is as follows (Safitri and Fidiana, 2014):

$$
\mathrm{SRDI}=\frac{\mathrm{v}}{\mathrm{M}}
$$

Where: SRD is Sustainability Report Disclosure Index Company, then $\mathrm{V}$ is number of items disclosed by the company, and $\mathrm{M}$ is number of items expected.

Data analysis techniques used in this study is Moderated Regression Analysis (MRA). The error rate $(\alpha)$ in this study set at $0.05(\alpha=5 \%)$. Conclusion is that if the significance calue $>0.05$, then the hypothesis is accepted

\section{RESULTS AND DISCUSSION}

Testing the hypothesis in this study was conducted using linear regression model in order to determine influence between the independent variable, the moderating variable, and the dependent variable. The independent variable tested in this study is Sustainability Report disclosure measured by SRDI, the dependent variable is the market performance measured using Tobin's $Q$ and the moderating variable consisting of environmental performance measured using PROPER. The linear regression equation formed is:

$$
\begin{gathered}
\mathrm{MP}_{1}=\alpha_{1}+\beta_{1}(\mathrm{SR})+\mathrm{e}_{1} \\
\mathrm{MP}_{2}=\alpha_{2}+\beta_{2} \mathrm{SR}+\beta_{3} \text { PROPER }+\beta_{4} \mathrm{SR}^{\star} \text { PROPER }+\mathrm{e}_{2}
\end{gathered}
$$

Where MP: market performance; $\alpha$ : constant; $\beta$ : regression coefficients, SR: sustainability report, PROPER; environmental performance, e: error.

Table 1 - First Model

\begin{tabular}{lrrr}
\hline & \multicolumn{3}{c}{ Nilai Perusahaan } \\
\cline { 2 - 4 } $\begin{array}{l}\text { Variable } \\
\text { Independen }\end{array}$ & $\begin{array}{c}\text { Unstandardiz } \\
\text { ed Coefficient } \\
(\beta)\end{array}$ & $\mathrm{t}$ & Sig \\
\hline (Constant) & 1.827 & 3.802 & 0.000 \\
\hline SR & -2.285 & -2.875 & 0.006 \\
\hline F Statistik & 8.264 & $0.006^{\mathrm{b}}$ \\
\hline $\mathrm{R}$ & & $0.341^{\mathrm{b}}$ \\
\hline $\mathrm{R}^{2}$ & & 0.116 \\
\hline Std. Error & & 0.877 \\
\hline b. Predictors: (Constant); SR & &
\end{tabular}


The first model is simple linear regression of it is distributed based on the results on the analysis as follows:

$$
\mathrm{NP}=1.827-2.285 \mathrm{SR}
$$

Constant value of 1.827 means that the market performance will increase by 1.827 times before or without the independent variables reflected in the SRDI. The sustainability report disclosure variable (SRDI) has a negative coefficient of 2.285 which means that every $1 \%$ increase in the sustainability report disclosure variable, the market performance will decrease by 2.285 times, assuming that if there are other independent variables are constant.

The result of the coefficient of determination $\left(R^{2}\right)$ test results in an R-squared value of 0.116 or $11.6 \%$, while the remaining $88.4 \%$ is influenced by other variables not included in this study. The $\mathrm{R}$ value of 0.341 or $34.1 \%$ indicated that the relationship between the sustainability report variable and market performance is not strong. The results of the $F$ test or simultaneous test on the first regression equation are obtained with a profitability value of 0.006 . The result of the $\mathrm{F}$ significance value is 0.006 and more that the significance level of 0.05 or $5 \%$, which indicates that SRDI variable has a significant value.

Table 2 - First Model

\begin{tabular}{lccc}
\hline \multirow{2}{*}{ Variable Independen } & \multicolumn{3}{c}{ Nilai Perusahaan } \\
\cline { 2 - 4 } & $\begin{array}{c}\text { Unstandardized } \\
\text { Coefficient }(\beta)\end{array}$ & $\mathrm{t}$ & Sig \\
\hline (Constant) & -0.022 & -0.290 & 0.850 \\
\hline SR & $-0.359^{\prime}$ & -3.010 & 0.004 \\
\hline PROPER & -0.086 & -0.680 & 0.499 \\
\hline SRxPROPER & 0.196 & 1.600 & 0.115 \\
\hline F Statistik & & 3.638 & $0.018^{b}$ \\
\hline$R$ & & & $0.390^{b}$ \\
\hline$R^{2}$ & & & 0.152 \\
\hline Std. Error & & & 0.943 \\
\hline b. Predictors: (Constant); SR
\end{tabular}

The second model is Moderated Regression Analysis (MRA) if distributed from the analusis results, the model is as follows:

$$
N P=-0.022-0.359 S R-0.086 P R O P E R+0.196 S R D I x P R O P E R+0.943 e
$$

The result of the regression equation above shows that the constant is 0.022 with a negative value, it means that the market performance will decrease by 0.022 times before or without the independent variables as reflected in SR and PROPER. The sustainability report disclosure variable has a negative regression coefficient of 0.359 which means that every in the sustainability report disclosure variable by $1 \%$, the market performance will decrease by 0.359 assuming a constant environmental performance.

The environmental performance variable has a negative regression coefficient with a value of 0.086 , which means that every $1 \%$ increase in the environmental performance variable, market performance will decrease by 0.086 , assuming the sustainability report disclosure is constant. The $F$ value in the second regression equation is 0.15 where $0.115>$ 0.05 , it means that environmental performance as a variable does not affect the sustainability report disclosure of market performance.

The $R^{2}$ value in this second equation has increased to 0.152 which means that the existence of environmental performance as a moderating variable cannot moderate the effect of sustainability report disclosure on market performance. The $R$ value of 0.390 indicates that the relationship between the sustainability report variable and market performance is considered not too strong, namely $39 \%$. 


\section{CONCLUSION}

Based on the results testing in table 1, it shows the results of the significance test of the sustainability report disclosure measured using SRDI on market performance as measured using Tobin's $Q$, obtaining a significance result of $0.006<0.05$. These results indicate that the disclosure of the sustainability report on firm value has an effect, so it can be concluded that first hypothesis is accepted. The results indicate that the disclosure of sustainability reports made by companies can increase market performance. The results obtained are accordance with the hypothesis that has been expressed, where the main objective of the company is to increase market performance.

This results supported by Latifah and Luhur's research (2017) which states that the disclosure of sustainability reports has a significant effect on company value, the reinforced by research by Fatcan (2016) and Kuzey \& Uyar (2017) which also state that the disclosre of sustainability reports has a positive effect on market performance. Research by Safitri also supported and state that sustainability report disclosure has a positive and significant effect on market performance.

However, the effect of sustainability report disclosure on firm value is considered insignificant, seen from the Beta value in the first hypothesis in the regression equation has a negative value, so it can be concluded that there is a negative effect between the disclosure of sustainability report on market value, therefore in the second hypothesis, the researches add variable moderation, namely environmental performance whether after adding the moderating variable, the effect of sustainability report disclosure on firm value can change to be significant.

The results of this study support signaling theory that the sustainability report disclosure reported by the company provides a positive signal to stakeholders. It is evident in this study, namely that the growth in company's market value is influenced by the disclosure of the sustainability report even though the effect is negative. This is because investors still evaluate the company through the financial performance listed in the annual report.

Based on the results of the regression test analysis using the MRA method or Moderated Regression Analysis in table 2, the disclosure of the sustainability report on market performance with environmental performance as assessed by PROPER as a moderating variable shows significance level of 0.115 where the number is greater than 0.05 , it means the second hypothesis is rejected.

This is because not all investors look through environmental performance as a criterion for making decisions in investing. For some investors, companies with good environmental performance are not necessarily companies that can benefit them. In addition, for investors, environmental management will increase the costs incurred by the company so that it will affect the company's profits because investors or shareholders, in addition to expecting profits from the company, also do not want to face the risk of losing capital.

Another reason is can also be caused by the lack of companies in the sample listed on the IDX participating in the PROPER program so that the PROPER ranking cannot describe the overall environmental performance. The existence of environmental performance does not affect company value the results of this study are in line with research by Sejati \& Prastiwi (2015) which states that disclosure of environmental performance has no effect on market value as proxied by Tobin's Q. it is possible that environmental performance is not significant in moderating the relationship between sustainability report disclosure and market performance due to stakeholder assumptions. Companies that do disclosure of environmental performance do not have a better value that companies that do not disclose environmental performance, because stakeholders prefer companies that take concrete actions without having to create an image by publishing environmental responsibility reports.

\section{REFERENCES}

1. A Chariri and Imam Ghozali. 2007. "Teori Akuntansi". Semarang: Badan Penerbit Universitas Diponegoro. 
2. Adams, M., Barry Thornton \& Mohammad Sepehri. 2011. The impact of the pursuit of sustainability on the financial performance of the firm. Journal of Sustainability and Green Business, No. 1, Vol 2.

3. Aldilla Noor Rakhiemah and Dian Agustia. 2009. Pengaruh Kinerja Lingkungan Terhadap Corporate Social Responsibility (CSR) Disclosure and Kinerja Finansial (Studi Empiris Pada Perusahaan Manufaktur Yang Terdaftar Di Bursa Efek Indonesia). Skripsi. Universitas Airlangga.

4. Almilia, Luciana Spica danWijayanto, Dwi. 2007. Pengaruh Environmental Perform- ance and Environmental Disclosure Terhadap Economic Performance. Proceed- ingsThe 1st Accounting Conference. Depok, 7 - 9 November 2007.

5. Anggrawal, Priyanka. 2013. Dampak Sustainability Reporting terhadap Kinerja Keuangan and Risiko Perusahaan (Studi Empiris Perusahaan yang Masuk Ke SRIKEHATI Tahun 2009-2010). Global 2 Journal of Management and Business Research Finance Vol. 13.

6. Chung, K. H. \& Pruitt, Stephen W. (1994). A Simple Approximation of Tobin's Q. Financial Management Journal, 23, 3, 26-41.

7. Darnall, Nicole., Henriques, Irene., Sadorsky, Perry. 2008. Do environmental management systems improve business performance in an international setting? Journal of International Management 14 (2008) 364-376.

8. Dewi, K. E. C., \& Sudana, I. P. (2015). Sustainability Reporting and Profitabilitas (Studi Pada Pemenang Indonesian Sustainability Reporting Awards). Jurnal IImiah Akuntansi and Bisnis.

9. Elkington, John. 1997. Cannibals with forks, the triple bottom line of twentieth century business, dalam Teguh Sri Pembudi. 2005. CSR. Sebuah Keharusan dalam Investasi Sosial. Jakarta: Pusat Penyuluhan Sosial (PUSENSOS) Departemen Sosial RI. La Tofi Enterprise.

10. Gunawan, Yovani and Sekar Mayangsari. 2015. Pengaruh Sustaibability Reporting terhadap Nilai Perusahaan dengan Investment Oportunity Set sebagai Variabel Moderating. Trisakti: e-Journal Akuntansi Vol. 2, No. 1.

11. Kuzey, Cemil \& Ali Uyar. 2017. Determinants of Sustainability Reporting and Its Impact on Firm Value: Evidence from the Emerging Market of Turkey. Journal of Cleaner Production. 143:27-39.

12. Latifah, S. W., \& Luhur, M. B. (2017). Pengaruh Pengungkapan Sustainability Report terhadap Nilai Perusahaan dengan Profitabilitas sebagai Pemoderasi. Jurnal Akuntansi and Bisnis, 17(1), 13-18.

13. Lesmana, Y. (2014). Pengaruh Sustainability Reporting Terhadap Kinerja Keuangan Perusahaan Publik dari Sisi Asset Management Ratios. Business Accounting Review, 2(1), 101-110.

14. Mardikanto, Totok. 2014. CSR (Corporate Social Responsibility) (Tanggung Jawab Sosial Perusahaan). Bandung: Alfabeta.

15. Pratiwi, Ririn Diah and Anna Sumaryati. 2014. Dampak Sustainability Reporting terhadap Kinerja Keuangan and Risiko Perusahaan (Studi Empiris Perusahaan yang Masuk Ke SRIKEHATI Tahun 2009-2010). Jurnal Dinamuka Akuntansi Vol. 6, No. 2.

16. Safitri, D. A., \& Fidiana. 2015. Sustainability Report Terhadap Kinerja Keuangan and Pasar. Jurnal IImu and Riset Akuntansi, 4(4), 15.

17. Sarumpaet, Susi. 2005. The Relationship between Environmental Performance and Financial Performance of Indonesian. Jurnal Akuntansi and Keuangan, 7 (2), 89-98

18. Sejati, Bima Putranto and Andri Prastiwi. 2015. Pengaruh Pengungkapan Sustainability Report terhadap Kinerja and Nilai Perusahaan. Universtias Diponegoro: Diponegoro Journal of Accounting Vol. 4, No. 1. ISSN Oline: 2337-3806. 